\title{
Listening to Art on a Seabed
}

Jana Horáková / horakova@phil.muni.cz

Department of Musicology, Faculty of Arts, Masaryk University, CZ

\begin{abstract}
The paper addresses Vilém Flusser's media philosophy, with a focus on his concept of new media art. Since Flusser never wrote a clear definition of new media art, his view must be deduced from remarks spread across his writings. The deduction is based on the assumption that Flusser's notion of new media art can be set up within the frame of Gaston Bachelard's water element aesthetics. In the paper, metaphors associated with water and with dreams are used to establish links among such different terms within Flusser's vocabulary as "sounding images and visible sound" (computed and projected models of collected data), "chamber mu-

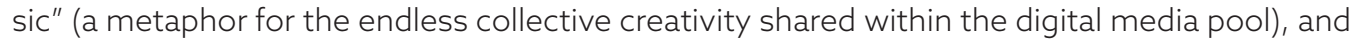
"Vampyroteuthis infernalis" (a fantastic creature living in the hostile environment of the oceanic abyss). The aim is to introduce Flusser as an author of an original and visionary aesthetic and of the poetics of new media art.
\end{abstract}

\section{Keywords}

water element aesthetics, new media art, sounding images, chamber music, Vampyroteuthis infernalis 


\title{
Vilém Flusser, The Water Element Media Philosopher
}

\author{
I live them synthetically in their original complexity, \\ often according them my unreasoning adherence. ${ }^{1}$
}

Vilém Flusser's way of thinking can be described as a form of intellectual play with ideas that revolve in whirlpools around questions such as: How will the technology-driven evolution of human society change humanity, human communication, human values, and human creativity? His essayistic and poetic style of writing, which is speculative rather than analytical, led some scholars to exclude Flusser's work from academic discourse ${ }^{2}$ and others to call him a poet-philosopher. ${ }^{3}$ Flusser's writings are in permanent flux, in a process of transformation and translation. He wrote most of his papers in three languages (German, Portuguese, and English) and he changed his arguments more or less every time he tried to fix his ideas on paper. His texts can be sorted into streams or clusters of arguments dealing with the same facts but with slight or significant changes both in the argumentation chains and in the conclusions that he poses. ${ }^{4}$

Gaston Bachelard would say that Flusser's thinking indicates that his element is water. The water element refers to pre-rational experiences, such as visions or dreams, that come to authors and which the authors must then transform into rational arguments. "I live them synthetically in their original complexity, often according them my unreasoning adherence", ${ }^{5}$ confessed Bachelard. The same can be said about Flusser's style of writing. This kind of thinking manifests itself in the fluidity of his arguments, which seem to be in permanent flux, circulating around the same subjects or topics. ${ }^{6}$ Similar imaginationdriven writing can be found in the texts that Flusser called fables, in which he dealt with possible technology-driven futures of humankind. ${ }^{7}$ Other writings took the character of rational arguments constructed around his personal experiences, the images, scenes, and events stored in something as insecure and fluid as personal memories. ${ }^{8}$

1 BACHELARD, Gaston. Water and Dreams: An Essay on the Imagination of Matter. Dallas: The Pegasus Foundation, 1983, p. 7.

2 Werner Faulstich refuses to accept Flusser's, Virilio's, or Baudrillard's texts as media theories, and does not consider them to be scientific or academic writings. See: LESCHKE, Rainer. Einführung in die Medientheorie. München: 2003, p. 273.

3 BERNARDO, Gustavo. FlusserBrasil [online]. 2014. Available on line: <http://flusserbrasil.com/index. html>. [Accessed: February 18, 2017].

4 Flusser used the Hebrew term pilpul to describe finding the meaning or possible truth of a text by approaching it from different perspectives (of languages or cultures or just unusual points of view).

5 BACHELARD, Gaston. Water and Dreams. An Essay on the Imagination of Matter. Dallas: The Pegasus Foundation, 1983, p. 7.

6 Compare with the meaning of the Hebrew word pilpul, footnote 4.

7 FLUSSER, Vilém. Into the Universe of Technical Images. Minneapolis: University of Minnesota Press, 2011. FLUSSER, Vilém; BEC, Louis. Vampyroteuthis Infernalis. A Treatise, with a Report by the Institut Scientifique de Recherche Paranaturaliste. Minneapolis: University of Minnesota Press, 2012.

8 See FLUSSER, Vilém. Bodenlos. Eine philosophische Autobiographie. Bensheim and Düsseldorf: Bollmann, 1992. 
The water-like and dream-like imagination is present in Flusser's writings in its ambivalence. His arguments balance between the two dominant modes of the water-element imagination mentioned by Bachelard: ${ }^{9}$ On one side, there are springtime, easy reflections, playing with the images of the future that are sparkling on the water-like surfaces; this can be compared with Flusser's tendency to play with concepts without using quotations, without needing to support his statements with references to evidence or examples, his allegorical and metaphorical way of thinking. On the other side, there are deep dives into the stagnant waters of the fundamental questions and values of human beings; these can be compared with Flusser's interest in the dialogical character of human existence in the world, his understanding of humanity as becoming, as a permanent process of transformation and redefinition, thus at permanent risk of being transformed so radically that it would be impossible to use the term human anymore. The water element also connects to Flusser's periodically expressed visons of new media art.

\section{Dreaming about New Media Art}

It will become pointless to try to distinguish between music and so-called visual arts because everyone will be a composer, will make images. The universe of technical images can be seen as a universe of musical vision. ${ }^{10}$

In September 1988, Flusser visited the European Media Art Festival in Osnabrück. It was the year when the festival of experimental film and video, established in 1982, displayed new media art for the first time. ${ }^{11}$

During the event, Vilém Flusser gave an interview in which he was asked to express his opinion about the media art he saw there. His answer summarizes his ideas about new media art and puts it into the wider context of a "cultural revolution" driven by the change of code from linguistic to mathematics, from the linearity of texts to the mathematical order of synthetic images. ${ }^{12}$ His answer is transcribed here almost in full [emphasis mine]:

I am here in Osnabrück for the following reason. I am impressed by the fact that one of the most important dimensions of the present cultural revolution is not sufficiently accentuated. Namely, the fact that linguistic communication, both the spoken and the written word, are no longer capable of transmitting

9 BACHELARD, Gaston. Ibidem, p. 7.

10 FLUSSER, Vilém. Into the Universe of Technical Images, p. 165.

11 The International Experimental Film Festival in Osnabrück changed its name to the European Media Art Festival, Osnabrück, in 1988, and its organisers expanded dramaturgy with other experimental media art forms. See the festival catalogue archives, available on-line: 〈http://emaf.de/english/archiv/festivals.html> [Accessed: February 22, 2017].

European Media Art Festival, Osnabrück, September 1-11, 1988. See catalogue, available on-line: <http:// emaf.de/files/emafkatalog1988webklein.pdf> [Accessed: February 22, 2017].

12 For more, see e.g.: FLUSSER, Vilém. Die Krise der Linearität. Kunstmuseum Bern. 1988. 
the thoughts and concepts which we have concerning the world. And new codes are being elaborated. And one of the most important codes is the code of technical images. So I came to Osnabrück to look at what those people are doing.

Let me explain a little bit what I mean. It has been clear for several centuries now that if we want to understand the world, it is not sufficient to describe it by words, it is necessary to calculate the world. So that science has had ever more recurrence to numbers which are images of thoughts [...] they are ideograms. Now, this ideographic code, which is the code of numbers, has been developed, in a very refined way, lately, by computers. Numbers are being transcoded into digital codes. And digital codes are, themselves, being transcoded into synthetic images. So, it is my firm belief that if you want, nowadays, to have a clear and distinct communication of your concepts, you have to use synthetic images, no longer words. And this is a veritable revolution in thinking. And I am very much interested in this, but I have to confess that as far as my experience in Osnabrück is concerned, I haven't seen much in this sense. The reason may be that people do not yet know how really to handle the new apparatus. ${ }^{13}$

Flusser expressed a certain disappointment with contemporary new media art production in the interview. It seems that he missed seeing works of art that would investigate the nature of calculated (synthetic) images, their materiality, and the specific character of the new medium (the mathematical logic, the binary code, the performativity of software, etc.). This kind of new media art - more analytical, investigative, and conceptual than playful and spectacular - could be found later, in the 1990s and especially after 2000. It is called software art or code work usually. ${ }^{14}$ The fact that Flusser was not satisfied with contemporary new media art production may be the reason that he never referred to particular art works and never mentioned any artists when he wrote about the new media art. It can be said that Flusser's concept of new media art was not a reflection of the new media art production of the time, but rather a form of dreaming about the new media art of the future.

13 FLUSSER, Vilém. On Writing, complexity, and the technical revolution. Interview in Osnabrück, European Media Art Festival, September 1988. Available online (published 13. 1. 2011): 〈https://www.youtube.com/ watch? $\mathrm{v}=$ lyfOcAAcoH8> [Accessed: February 22, 2017].

14 HORÁKOVÁ, Jana. The Gestures That Software Culture Is Made Of. In MAP - Media / Archive / Performance, Leipzig, Germany: Hochschule für Musik und Theater "Felix Mendelssohn Bartholdy". 2016, No. 7, p. 1-18. Available online: <http://www.perfomap.de/map7/media-performance-on-gestures/the-gestures-thatsoftware-culture-is-made-of $>$ [Accessed: February 22, 2017]. 


\section{The Images That Sing}

'A new imagination' is what Flusser, after all, hoped for. ${ }^{15}$

Flusser was dreaming about a new kind of synthetic imagination that would be the result of certain tendencies of the electronic media production: "[...] the tendency of technical images to become more and more immediate and to repress texts or the tendency of images to become electronic or the tendency of apparatuses to become smaller and cheaper and to penetrate into the smallest spaces." 16

The synthetic character of the new imagination refers not only to the quality of the projected electronical images, but to their synthesis on a structural level. ${ }^{17}$

Flusser turns our attention to the materiality of the technical images produced by computers (digital images), asserting that it is more like the universe of music than like the visual arts with their strong tradition based on mimesis as representation. Flusser stated that "compose and compute are synonyms" 18 and that "the universe of music is as calculated and computed as that of technical images." ${ }^{19}$ He concluded that digital images are computed or composed in a sense that was previously assigned exclusively to works of music. In his words, "It will become pointless to try to distinguish between music and so-called visual arts because everyone will be a composer, will make images. The universe of technical images can be seen as a universe of musical vision." ${ }^{20}$ Following these propositions, Flusser claimed that the new art of the future will take the form of "sounding images and visible sound."11

Flusser found forebears of the new media art in abstract paintings and scores of newer musical compositions. However, he noted that efforts to make music pictorial and pictures musical can be fulfilled only within electronic media, because only the "synthesized images are really conceived musically and made musical with visualizing power." 22 He explicitly distinguished the art of the sounding images from cases of using electronic mixers that automatically translate images into sounds and sounds into images, because the sounding image is not an image mixed with music; rather, "both are raised to a new

15 Silvia Wagnermaier, in reference to a paper by ZIELINKSI, Siegfried. Vilém Flusser: A brief introduction to his media philosophy. Vilém Flusser's view on art. MECAD online seminar. Cologne, September 2004. Available online: 〈https://monoskop.org/images/4/4b/Flussers_View_on_Art_MECAD_Online_Seminar.pdf> [Accessed: February 22, 2017].

16 FLUSSER, Vilém. Into the Universe of Technical Images, p. 160.

17 Compare with Dick Higgins's concept of intermedia, elaborated in HIGGINS, Dick. Synesthesia and Intersenses: Intermedia. 1965. Originally published in Something Else Newsletter 1, No. 1 (Something Else Press, 1966). Also published as a chapter in Dick Higgins, Horizons, the Poetics and Theory of the Intermedia (Carbondale, IL: Southern Illinois Univ. Press, 1984). Available online: <http://www.ubu.com/papers/higgins_intermedia.html\#top> [Accessed: February 22, 2017].

18 FLUSSER, Vilém. Into the Universe of Technical Images, p. 164.

19 Ibidem, p. 164.

20 Ibidem, p. 165.

21 Ibidem, p. 166

22 Ibidem, p. 165. 
level, the audiovisual." ${ }^{23}$ He concluded that it made no sense to distinguish among images, texts, or music in the universe of synthetic (digital) images, because everything is subject to the logic of the computation (composition).

The sounding image is made by a programming language that directs the computer to perform specific operations. The performativity of the algorithms that produce the new quality of the synthetic images led Flusser to call them "ideograms that work." ${ }^{24}$ A classical conceptual software work of art, Every Icon ${ }^{25}$ by John F. Simon, Jr. from 1996, is a good demonstration of the difference between the technical image (e.g. a photograph or film) and the sounding image (the ideogram that works). Every Icon is a short and simple program:

\section{Given: A 32 X 32 Grid \\ Allowed: Any element of the grid \\ to be black or white \\ Shown: Every Icon}

Every Icon progresses by counting. ${ }^{26}$ Starting with an image in which every grid element is white, the software displays combinations of black and white elements, proceeding towards an image where every element is black. Thus, Every Icon is not an image in the sense of visual art; it is a visualisation of the program processing, the manifestation of computation. Unlike an image projection (as with film, for example), viewers are watching the image performance (the program processing) in real time. Every Icon is a minimalistic yet conceptually complex example of the new media work of art materiality that Flusser addressed with the notion of "sounding image". We can say that it is an image singing its composition. To understand its nature, watching the screen is not enough. One must dip beneath the surface of the computer screen to become acquainted with the program, composition, and concept behind it.

\footnotetext{
23 Ibidem, p. 165.

24 FLUSSER, Vilém. Our shrinking. In Siegfried Zielinski (ed.), Post-History. Univocal 2013, p. 79.

25 SIMON Jr., John. Every Icon. 1996. Available online: <http://www.numeral.com/articles/paraicon/ paraicon.html> [Accessed: February 22, 2017].

26 Ibidem.
} 


\section{The Pool of Singing Images}

[...] not Euclidian space but dataspace that is fugitive, fleeting, more akin to water or wind in its ephemeral, flowing materiality, than to the granite permanency of traditional works of art. ${ }^{27}$

According to Flusser, new media production is the effect of the apparatus-operator complex ${ }^{28}$ functioning: "the apparatus-operator complex devours texts, to spit them out again as techno-images." ${ }^{29}$ The plural (techno-images) expresses the way these images exist. Each of them refers to and stands for the whole realm of the technical images that Flusser called the universe of technical images. The 1988 Osnabrück media festival catalogue (the year that Flusser visited the festival and gave the interview quoted above), published Roy Ascott's article Superconnectivity in Deep Dataspace in which he described "dataspace" or "telematic space" and congenially elaborated, in depth and in a poetic style, Flusser's notion of the universe of technical images. Ascott explained that it is "not Euclidian space but dataspace that is fugitive, fleeting, more akin to water or wind in its ephemeral, flowing materiality, than to the granite permanency of traditional works of art." ${ }^{30} \mathrm{He}$ argued that it is a place in which we can play "creatively, productively, ritically, and theoretically" 31 and used metaphors invoking the liquid materiality and dream-like experience of the new space. He reminded readers that dataspace is not situated behind the screen of the computer, in opposition to our physical world, but is "the environment we now inhabit. It will eventually condition all aspects of the environment, both spiritually and physically." 32 Both Flusser and Ascott anticipate an advent of "synthetic image" dataspace that will bring about a new kind of consciousness and set new rules of the game.

27 ASCOTT, Roy. Superconnectivity in Deep Dataspace. In European Media Art Festival (catalogue), Osnabrück: 1988, p. 334-336. Available online: 〈http://emaf.de/files/emafkatalog1988webklein.pdf> [Accessed: February 18, 2017].

28 The apparatus-operator complex is a dispositive of post-industrial societies. It is a result of Flusser's phenomenological analyses of man-machine interactions.

29 FLUSSER, Vilém. Kommunikologie, Schriften 4, ed. Vera Eckstein and Stefan Bollmann. Mannheim: Bollmann, 1996, p. 151.

30 ASCOTT, Roy. Superconnectivity in Deep Dataspace, p. 334-335.

31 Ibidem, p. 335.

32 Ibidem, p. 335. 


\section{Chamber Music and Close Circuits}

[...] pure play, by and for the players, for whom listeners are superfluous and intrusive. ${ }^{33}$

The constitutive principle of the universe of sounding images, the dataspace or the telematic space, is the cybernetic loop. The repetitive movements in loops are involved in all practices connected with programmed digital media. ${ }^{34}$ Lev Manovich described the cyclical character of programmed media production while illustrating the logic of the computer and its influence on our culture (culture transcoding): "The logic of a computer [...] to produce endless variations of elements and act as a filter, transforming its inputs to yield a new outputs [...] becomes the logic of culture at large." 35 Vilém Flusser's notion of a telematic society is based on a concept of a cybernetic loop that sets the conditions for: "The consensus between image and person, strengthened automatically through feedback, [that] turns everyone into receivers, whether they were initially willing or not. And this consensus forms the core of a society governed by technical images. A closed feedback circuit appears to have been set up between image and person." 36

Flusser uses the metaphor of chamber music to depict the character of the cybernetic loop principle within which the post-industrial society is settled. According to him chamber music shares many aspects with post-industrial communication. Thus " [c]hamber music can serve as a model of telematic social structure. [... ] it precedes telematics, the apparatus, and automation [...]. It is now possible to see in it (and perhaps in jazz, so strongly reminiscent of chamber music) many aspects of post-industrial communication." ${ }^{37}$ In the last chapter of his book Into the Universe of Technical Images, he introduces the scenario of a telematic society of the future, using the metaphor of a chamber orchestra performance:

[...] I propose here is this: people will sit in separate cells, playing with their fingertips on keyboards, staring at tiny screens, receiving, changing, and sending images. [... ] People will be in contact with one another through their fingertips and so form a dialogical net, a global superbrain, whose function will be to calculate and compute improbable situations into pictures, to bring information, catastrophes about. [...] In terms of function, then, it will be meaningless to try to distinguish between natural and artificial intelligences [...]. The whole thing will function as a cybernetically controlled system that cannot be divided into constituent elements [...]. ${ }^{38}$

33 FLUSSER, Vilém. Into the Universe of Technical Images, p. 162.

34 CHUN, Wendy Hui Kyong. Programmed Visions: Software and Memory. Cambridge, Mass.: MIT, 2011, p. xi-xii.

35 MANOVICH, Lev. The Language of New Media. Cambridge, Mass.: MIT, 2001, p. 236.

36 FLUSSER, Vilém. Into the Universe of Technical Images, p. 55.

37 Ibidem, p. 163.

38 Ibidem, p. 161. 
Chamber music was long performed in private by amateur musicians who came together to play music for their own pleasure. "It is cybernetic," noted Flusser, because it is "pure play, by and for the players, for whom listeners are superfluous and intrusive. It employs participation (strategy) rather than observation (theory)." ${ }^{39}$ Flusser stressed the dialogical and participatory character and the lack of self-awareness of the musicians, replaced by the endless circulation of information within the network that interconnects the apparatuses and their functionaries into one whole.

The cybernetic character of the apparatus-operator complex production was addressed by Axel Bruns using the term "produsage" ${ }^{40}$ (an abbreviation of production and usage) to refer to the collapse of the production and consumption dichotomy that is replaced by a closed circuit of endless participation and collaboration. Examples of these kinds of cultural production strategies are remake, remix, postproduction, appropriation, and the viral distribution of memes. In all of these practices, the cyclical character of the loop can be found as a principal logic.

These examples of typical productions within dataspace are in concomitance with Flusser's thinking. However, the metaphor of the chamber orchestra performance refers not only to the participatory character of the production, but also to the absence of reflective (theoretical) thinking; such thinking is possible only when one cuts the flux of information exchange and steps back to look on the arrangement from a distance. That is why the state of mind that the apparatus-operator complex produces takes on the character of dreaming.

\section{Whirlpools and Surface Play}

superficial images [...] play on the surface of an element without giving the imagination time to work upon matter. ${ }^{41}$

The cyclical character of production trapped in a cybernetic loop can be likened to the play of reflections on water surfaces. "Surface play" is a term used by Andrew Darley ${ }^{42}$ to characterize the typical strategy of technical image production and reception that spread in connection with the popular postmodernism tactics of consumption. Surface play refers to the popular entertainment formats of the 19th century, providing astonishing special effects and fantastic illusions to evoke sensual pleasures. In postmodernism, the spectacle gained a new stage in the play between quotations, parodies, and allusions on one side, and immersive experiences provided by digital technologies (e. g. video games) on the other. ${ }^{43}$

39 Ibidem, p. 162.

40 BRUNS, Alex. Blogs, Wikipedia, Second Life, and Beyond: From Production to Produsage. New York: Peter Lang, 2008.

41 BACHELARD, Gaston. Water and Dreams. An Essay on the Imagination of Matter, p. 10.

42 DARLEY, Andrew. Visual Digital Culture: Surface Play and Spectacle in New Media Genres. London and New York: Routledge, 2000.

43 See the definition of the word immersion in: LISTER, Martin et al. New Media. A Critical Introduction. London and New York: Routledge, 2003, p. 387. 
Flusser addressed the surface play experience using the metaphor of a chamber orchestra performance. The group of people and instruments in collective improvisation is a metaphor for the interaction of humans with dataspace in a kind of (surface) play that takes place within the computer screen- keyboard-fingers-brain arrangement. The player's session seems to be a trap akin to that of Narcissus. They are playing on their computer keyboards and enjoying images on their screens without realizing that they have gotten lost in a reflections made of images of images of images...

This kind of experience is usually described by the word immersion, which normally refers to being under the surface of or in a body of liquid. However, in the context of new media theory it refers to the experience of being inside the world of synthetic images, in which the subjects lose the sense of themselves as separate from the medium or its simulated world. However, extending the metaphor of water, I would compare this kind of experience of human-synthetic image interaction to swimming or snorkelling: just safe, comfortable, playful fun.

\section{Ocean Abysses and Vampyroteuthis Infernalis}

"The text Vampyroteuthis Infernalis [...] is deliberately provocative in its formulations in order to stimulate thinking about the present and the future." ${ }^{4}$

Images flickering on screens can be likened to the reflections on water surfaces that Bachelard described as "superficial images that play on the surface of an element without giving the imagination time to work upon matter." ${ }_{45}$ He encourages recipients to overcome the surface play trap, the (cybernetic) loop of circulating images, and to see through the water, in the sense of seeing in depth and also seeing beyond: "The lake or pool or stagnant water stops us near its bank. It says to our will: you shall go no further; you should go back to looking at distant things, at the beyond."46

Flusser shares with Bachelard the idea that it is necessary to look from a distance at things and to look beyond these things to be able to really know them. But instead of standing and contemplating on a seashore, he takes us on an adventurous journey under the water's surface to meet with a fantastic and still real creature: Vampyroteuthis infernalis, the vampire squid.

Through "sounding images" Flusser addressed materiality and the structural quality of the new media art. He approached the poetics of telematic society production (including art) by means of the uneasy comparison with the fantastic Vampyroteuthis infernalis. The vampire squid is the closest relative of the octopus's earliest ancestor, which is still in many aspects one of the most interesting members of the Cephalopoda, albeit one of the smaller ones. It is a mollusc inhabiting the dark waters of the oceanic abyss. The creature

44 BOZZI, Paola. Vampyroteuthis Infernalis. In Siegfried Zielinski - Peter Weibel - Daniel Irrgang et al: Flusseriana. An Intellectual Toolbox. Univocal, 2015, p. 430.

45 BACHELARD, Gaston. Water and Dreams, p. 10.

46 Ibidem, p. ix. 
and its environment are presented as exact opposites to humans and their environment. However, Flusser uses the comparison not to describe the differences between humans and molluscs, but as a rhetorical figure enabling him to remind us that these differences are complementary rather than contradictory. We can interpret the mollusc as a virtuality of man, or as a carnival or grotesque image of humans of the possible future.

Not one of wakeful reason, the vampyroteuthic world is rather one of dreams. In this regard our respective Daseins are not radically different. As complex beings with complex brains, we are both partially rational and partially oneiric, and yet these two levels of consciousness are inversely proportioned between us. What to us is wakeful consciousness is, to its, the subconscious, a fact that manifests itself phenomenally in its stance toward life: head down, belly up. It is critique of pure reason is our psychoanalysis. ${ }^{47}$

The mollusc's life serves Flusser as a metaphor for the telematic society of the future that will be a result of the ongoing transformation of human communication, culture, and art towards abstraction and dematerialisation. According to Flusser, the mollusc's art does not involve the production of artificial memories (artefacts, objects) but intersubjective and immaterial communication, i.e. the immediate inclusion of data in the brains of those that perceive it. ${ }^{48}$ The mollusc's art is reminiscent of the oneiric experience of the production and consumption of synthetic images - the "software processing" - within the cybernetic loops in the dataspace. Flusser explicitly points to analogies between the mollusc's methods of interaction and "the new communicative media [that] may not be bioluminescent organs, but they are similarly electromagnetic." ${ }^{49}$ His argument leads to the conclusion that human evolution is heading towards the conditions of the mollusc. As Flusser puts it: "A vampyroteuthic revolution is underway." ${ }^{0}$

\section{Conclusion: Deep Diving and the Poetics of New Media Art}

"The eye assigns them names, but only the hand truly knows them."

Both Bachelard and Flusser are convinced that it is not the formal quality of composition or the motif but the materiality of the media that provides the key for understanding the character and meaning of the new media art. Flusser invites us to plunge into depths of hostile abysses to experience its materiality and to see beyond the world as we know it. He calls for deep diving into the liquid materiality of the water element to investigate the bios of these (for human) hostile places, even to reach the bottomless oceanic abyss.

The allegory of the mollusc living in the oceanic abyss (the abysses of the data pool) introduces us to Flusser's vision of a dystopian future with humans trapped within the

47 FLUSSER, Vilém; BEC, Louis Vampyroteuthis Infernalis, p. 41.

48 Ibidem, p. 65.

49 Ibidem, p. 65.

50 Ibidem, p. 65.

51 BACHELARD, Gaston. Water and Dreams, p. 1. 
endless play of synthetic images providing easy, sensual pleasures (the surface play of a chamber orchestra). However, between the lines in his book can be found another story, the story of a diver (an adventurous scientist or artist) who undertakes a dangerous journey into the depths of the oceanic abyss to investigate and analyse the materiality of the dataspace. The deep diving can serve as a metaphor for the tactics and escape routes that make it possible to overcome the trap of cybernetic circuits and the surface play of synthetic images. The deep diving is the opposite of mere immersion in the play of reflections and the theory. It refers to the experience that goes beyond our common sense and habits and even beyond our anthropocentric world. The risky plunge into the dataspace provides the diver with "hands on" experience with the dataspace materiality (the nature of programing codes and the logic of numbers and mathematic structures and processes).

In opposition to the surface play of images, the experience of the environment of the oceanic abyss is aural in its complexity rather than visual: the darkness pushes us to perceive these sounding images (the soft creatures, the molluscs) as sonar signals. We have to let them resonate through our bodies. Moreover, the pressure of the water in the abyss reminds us of the transformative power of the digital apparatus, its liquidity refers to the variability and fluidity of the dataspace. Deep diving into the darkness of the abyss can be metaphorically read as a message that the visual information will blind the viewer to the qualities of the medium, but aural (bodily and conceptual) experiences can have a transformative influence on the brain that can even change the way we see the computer - the dataspace of singing images.

Moreover, the metaphor of deep diving refers to the poetics of new media art in the sense that Flusser understands art: as a gesture of liberation.

Art is the master paradox of the Flusserian pluriverse, appearing here and there under certain conditions, distributed when pinpointable, removed from the world even as it operates at the level of the everyday, volatile yet often achieving concrete form, archeiropoetic yet sometimes automatizable. As such, it is neither a branch of learning per se nor a set of objects of whatever sort, but rather the name given to a range of perpetually morphing methods and models, ratios and calibrations, distinct from, and irreducible to, matters of skill, design, performance, aesthetics, culture, magic, or creativity. Entailing potent combinations of intentions, errors, and chance, art, above all, accomplishes its work as a mode of antideterminism and means of liberation. ${ }^{52}$

It is not possible to conclude this paper with any definition of new media art found directly in Flusser's writings. For Flusser, art was not the medium itself but the creative gesture of liberation - liberation from compulsory movements and automatisms provided by the apparatus-operator complex functioning. ${ }^{53}$

52 OLIVER, Anne-Marie. Art. In Siegfried Zielinski - Peter Weibel - Daniel Irrgang, et al: Flusseriana. An Intellectual Toolbox. Univocal, 2015, p. 58-60.

53 Compare with: Flusser, Vilém. Towards a General Theory of Gestures. In: Gestures. University of Minnesota Press, 2014. 


\section{Bibliography}

ASCOTT, Roy. Superconnectivity in Deep Dataspace. In European Media Art Festival (catalogue), Osnabrück: 1988,p.334-336.Availableonline:<http://emaf.de/files/emafkatalog1988webklein. pdf> [Accessed: February 18, 2017].

BACHELARD, Gaston. Water and Dreams. An Essay on the Imagination of Matter. Dallas: The Pegasus Foundation, 1983.

BERNARDO, Gustavo. FlusserBrasil [online]. 2014. Available online:

< http://flusserbrasil.com/index.html>. [Accessed: February 18, 2017].

BOZZI, Paola. Vampyroteuthis Infernalis. In Siegfried Zielinski - Peter Weibel - Daniel Irrgang et al: Flusseriana. An Intellectual Toolbox. Univocal, 2015 .

BRUNS, Alex. Blogs, Wikipedia, Second Life, and Beyond: From Production to Produsage. New York: Peter Lang, 2008.

DARLEY, Andrew. Visual Digital Culture: Surface Play and Spectacle in New Media Genres. London and New York: Routledge, 2000.

European Media Art Festival, Osnabrück, September 1-11, 1988. Catalogue, available online: <http://emaf.de/files/emafkatalog1988webklein.pdf> [Accessed: February 22, 2017].

FLUSSER, Vilém. Die Krise der Linearität. Kunstmuseum Bern, 1988.

FLUSSER, Vilém: On Writing, complexity, and the technical revolution. Interview in Osnabrück, European Media Art Festival, September 1988. Available online (published 13. 1. 2011): 〈https:// www.youtube.com/watch?v=lyfOcAAcoH8>, [Accessed: February 22, 2017].

FLUSSER, Vilém. Bodenlos. Eine philosophische Autobiographie. Bensheim and Düsseldorf: Bollmann, 1992.

FLUSSER, Vilém. Kommunikologie, Schriften 4, ed. Vera Eckstein and Stefan Bollmann. Mannheim: Bollmann, 1996.

FLUSSER, Vilém. Into the Universe of Technical Images. Minneapolis: University of Minnesota Press, 2011.

FLUSSER, Vilém; BEC, Louis. Vampyroteuthis Infernalis. A Treatise, with a Report by the Institut Scientifique de Recherche Paranaturaliste. Minneapolis: University of Minnesota Press, 2012.

FLUSSER, Vilém. Our shrinking. In Siegfried Zielinski (ed.), Post-History. Univocal 2013, p. 79.

FLUSSER, Vilém. Towards a General Theory of Gestures. In: Gestures. University of Minnesota Press, 2014.

HORÁKOVÁ, Jana. The Gestures That Software Culture Is Made Of. In MAP - Media / Archive / Performance, Leipzig, Germany: Hochschule für Musik und Theater "Felix Mendelssohn Bartholdy", 2016, No. 7, p. 1-18. Available online: 〈http://www.perfomap.de/map7/media-performanceon-gestures/the-gestures-that-software-culture-is-made-of> [Accessed: February 22, 2017].

HIGGINS, Dick. Synesthesia and Intersenses: Intermedia. 1965. Originally published in Something Else Newsletter 1, No. 1 (Something Else Press, 1966). Also published as a chapter in Dick Higgins, Horizons, the Poetics and Theory of the Intermedia (Carbondale, IL: Southern Illinois Univ. Press, 1984). Available online: <http://www.ubu.com/papers/higgins_intermedia. html\#top> [Accessed: February 22, 2017].

CHUN, Wendy Hui Kyong. Programmed Visions. Software and Memory. Cambridge, Mass.: MIT, 2011.

LESCHKE, Rainer. Einführung in die Medientheorie. München: 2003.

LISTER, Martin et al. New Media. A Critical Introduction. London and New York: Routledge, 2003. 
MANOVICH, Lev. The Language of New Media. Cambridge Mass.: MIT, 2001.

OLIVER, Anne-Marie. Art. In Siegfried Zielinski - Peter Weibel - Daniel Irrgang et al: Flusseriana. An Intellectual Toolbox. Univocal, 2015, p. 58-60.

SIMON Jr., John: Every Icon. 1996. Available online: <http://www.numeral.com/articles/paraicon/ paraicon.html> [Accessed: February 22, 2017].

ZIELINKSI, Siegfried. Vilém Flusser: A brief introduction to his media philosophy. Vilém Flusser's view on art. MECAD online seminar. Cologne, September 2004. Available online: <https://monoskop. org/images/4/4b/Flussers_View_on_Art_MECAD_Online_Seminar.pdf> [Accessed: February 22, 2017]. 